\title{
Peroxide scavenging potential of ultraviolet-B-absorbing mycosporine-like amino acids isolated from a marine red alga Bryocladia sp.
}

\author{
Vinod K. Kannaujiya, Richa and Rajeshwar P. Sinha* \\ Laboratory of Photobiology and Molecular Microbiology, Department of Botany, Centre of Advanced Study in Botany, Banaras Hindu University, Varanasi, India
}

Edited by:

Peter Rolf Richter,

Friedrich-Alexander-University,

Germany

\section{Reviewed by:}

Olimpio Montero, Spanish Council for Scientific Research (CSIC), Spain Shailendra Pratap Singh, Michigan State University, USA

\section{*Correspondence:}

Rajeshwar P. Sinha, Laboratory of Photobiology and Molecular Microbiology, Centre of Advanced Study in Botany, Banaras Hindu University, Varanasi-221005, India e-mail: r.p.sinha@gmx.net

\begin{abstract}
Ultraviolet-B (UV-B; 280-315 nm)-absorbing mycosporine-like amino acids (MAAs) were extracted and purified from a marine red alga Bryocladia sp. by using high performance liquid chromatography. We have detected four MAAs having retention times 3.23, 2.94, 3.56 , and $2.67 \mathrm{~min}$ with absorbance maxima $(\lambda \max )$ at $323,328,335$, and $340 \mathrm{~nm}$, respectively. The effect of UV-B on the induction of these MAAs was studied. In comparison to control, there was 3-22\% induction of MAAs after 12 and $24 \mathrm{~h}$ of UV-B exposure. Apart from MAAs, other pigments such as chl $a$, carotenoids and total proteins were inversely affected by UV-B irradiation. In addition, peroxide scavenging potential of these MAAs were also investigated. With $2 \mathrm{mM}$ hydrogen peroxide $\left(\mathrm{H}_{2} \mathrm{O}_{2}\right)$ concentration, only $<5 \%$ of MAAs were found to be affected. However, with the increased $\mathrm{H}_{2} \mathrm{O}_{2}$, 40-60\% decline in the MAAs concentration with a corresponding peak shifting toward the blue wavelength was recorded. In addition, most of the MAAs were found to be reacting slowly with increasing $\mathrm{H}_{2} \mathrm{O}_{2}$ (upto $10 \mathrm{mM}$ ) concentration after an incubation period of 5 and $30 \mathrm{~min}$, which indicates the remarkable scavenging potential and stability of MAAs against oxidative stress. Thus, the isolated MAAs from marine red alga Bryocladia sp. may act as an efficient peroxide scavenger.
\end{abstract}

Keywords: Bryocladia sp., mycosporine-like amino acids, hydrogen peroxide, UV-B irradiation, pigmentation

\section{INTRODUCTION}

Earth's atmosphere is surrounded by ozone layer in the stratosphere, which absorbs harmful ultraviolet radiation to protect the living beings (Lee and Shiu, 2009). Anthropogenically and naturally released atmospheric pollutant such as chlorofluorocarbons (CFCs), chlorocarbons (CCs), organobromides (OBs), and nitrogen containing reactive species $\left(\mathrm{NO}, \mathrm{ONOO}, \mathrm{N}_{2} \mathrm{O}\right)$ are potentially responsible for continuous declining of ozone layer since 1970 (Crutzen, 1992; Russell et al., 1996; Ravishankara et al., 2009). The UV-B radiation $(280-315 \mathrm{~nm})$ on the Earth's surface has increased due to depletion of the stratospheric ozone layer (Hoffman and Deshler, 1991; Madronich et al., 1998; Sahoo et al., 2005). Ultraviolet radiation is highly energetic short wavelength radiation that can penetrate up to 70 meter in sea water column (Smith et al., 1992). Ambient UV-B radiation is more harmful at low altitude sea level due to high solar angle and reduction in the thickness of ozone layer which penetrates deeper water column of sea (Lee and Shiu, 2009). These assumptions suggest that tropical regions of the world face higher impact of UV-B radiation as compared to the polar and temperate region (Häder, 1993). UV-B radiation has been reported to have the negative impact on the life forms of terrestrial (Ballaré et al., 2011) as well as aquatic ecosystems including photosynthetic cyanobacteria, algae and phytoplankton (Häder et al., 2011).

UV-B radiation may severely affect the physiological and biochemical processes such as specific growth rate, photosynthesis,
$\mathrm{CO}_{2}$ uptake, inorganic, and organic nutrient uptake, DNA damage and destruction of proteins of several organisms thereby reducing the productivity of ecosystems (Rastogi et al., 2011; Pessoa, 2012; Richa et al., 2013). In addition, extensive exposure may have drastic effect on the photosynthetic electron transport system, resulting in excessive ROS production leading to oxidative stress and consistent damage of cells (Langebartels et al., 2000). UV-B-induced oxidative stress has been observed in micro as well as macroalgae (He and Häder, 2002; Rijstenbil, 2002; Shiu and Lee, 2005). However, certain organisms have developed defense mechanisms such as induction of photoprotective compounds, scavenging of free radicals, photorepair, and programmed cell death that counteract the damaging effects of UV radiation (Janknegt et al., 2008; Lee and Shiu, 2009; Rastogi and Incharoensakdi, 2013). Interestingly, most of the algae have evolved to synthesize mycosporine-like amino acids (MAAs) that efficiently absorb UV-B radiation and scavenges the reactive oxygen species (ROS) to protect the cells (Riegger and Robinson, 1997; Dunlap and Shick, 1998; Conde et al., 2000).

MAAs are colorless, water soluble, and small $(<400 \mathrm{Da})$ nitrogenous substances structurally characterized by an aminocyclohexenone or aminocyclohexenimine ring chromophore conjugated with the nitrogen substituent of an amino acid or imino alcohol group, having absorption maxima between 310 and $362 \mathrm{~nm}$ (Nakamura et al., 1982; Sinha et al., 2007). MAAs have very high molar extinction coefficient $(\varepsilon=28$, 
100-50,000 $\mathrm{M}^{-1} \mathrm{~cm}^{-1}$ ) with photosensitized chromophore that indicates additional photo stability in both terrestrial as well as aquatic habitats (Shick and Dunlap, 2002).

UV-B radiation has been shown to have remarkable inhibitory effects on photosynthetic electron transport and photochemical reaction thereby (Foyer et al., 1994; Shimizu et al., 2010) inducing the ROS formation (Langebartels et al., 2000). Enhanced ROS production causes rapid disruption of macromolecules (Rijstenbil, 2002). The cyanobacteria have developed enzymatic as well as non-enzymatic defense mechanisms in order to avoid excessive ROS production (Wada et al., 2013). Hydrogen peroxide is most efficient ROS inevitably produced as by-products in photochemical reactions. The detoxification of hydrogen peroxide has been attributed by catalase, peroxidase and ascorbic peroxidase (Karyotou and Donaldson, 2005). In the present investigation an attempt has been made to elucidate the stability and scavenging potential of MAAs against peroxide.

\section{MATERIALS AND METHODS}

\section{GEOGRAPHICAL REGION AND COLLECTION OF ALGAL MATERIAL}

The test organism Bryocladia sp. (Sahoo et al., 2001) belonging to the family rhodophyceae was collected from the rock surface near Bheemli beach $\left(17^{\circ} 46^{\prime} 49.13^{\prime \prime} \mathrm{N}, 83^{\circ} 23^{\prime} 10.98^{\prime \prime} \mathrm{E}\right)$, Vishakhapatnam, Andhra Pradesh, India (Figure 1A). The morphology of alga was observed by light microscopy (Dewinter Light Microscope, New Delhi, India). The alga was growing in close association with the green alga Ulva sp. (Figure 1B). Bryocladia sp. is dark red-brown in color, prostrate, polysiphonous branchlets spirally arranged with $2-5 \mathrm{~cm}$ long plant height (Figures 1C,D).

\section{SOURCE AND MODE OF UV-B IRRADIATION}

Algal sample was thoroughly washed with Mili Q water, transferred into sterile transparent Petri dishes $(75 \times 75 \mathrm{~mm})$ filled with artificial sea water and placed on a rotary shaker for uniform exposure of $1 \mathrm{Wm}^{-2} \mathrm{UV}-\mathrm{B}$ radiation reaching to the culture (Philips Ultraviolet-B TL $40 \mathrm{~W}: 12$, Holland). Temperature was maintained at $20 \pm 5^{\circ} \mathrm{C}$ to avoid heat shock effects. A $295 \mathrm{~nm}$ cutoff filter foil (Ultraphan, UV Opak Digefra, Munich, Germany) was used to get the required regime of UV-B radiation. Aliquots $(1.0 \mathrm{~g})$ were withdrawn after 12,24 , and $48 \mathrm{~h}$ of UV-B irradiation. All the experiments were done twice (in triplicates) with consistently the same results.

\section{EXTRACTION AND PURIFICATION OF MYCOSPORINE-LIKE AMINO ACIDS (MAAs)}

Extraction and purification of MAAs were done following the method of Sinha et al. (1999). Briefly, the samples were homogenized in $100 \%$ methanol (HPLC grade, Spectrochem, Mumbai) with the help of Mortar and Pestle and incubated for $24 \mathrm{~h}$ at $4^{\circ} \mathrm{C}$. Thereafter, aliquots were centrifuged at $5000 \mathrm{~g}$ for $5 \mathrm{~min}$. The supernatant was evaporated to dryness, redissolved in $1 \mathrm{ml}$ Mili Q water and centrifuged (10000 g for $10 \mathrm{~min})$ to remove the pigment contamination. The supernatant was filtered through $0.2 \mu \mathrm{m}$ (Axiva Biotech., New Delhi) size membrane filter. Further purification and separation of MAAs was done by HPLC.

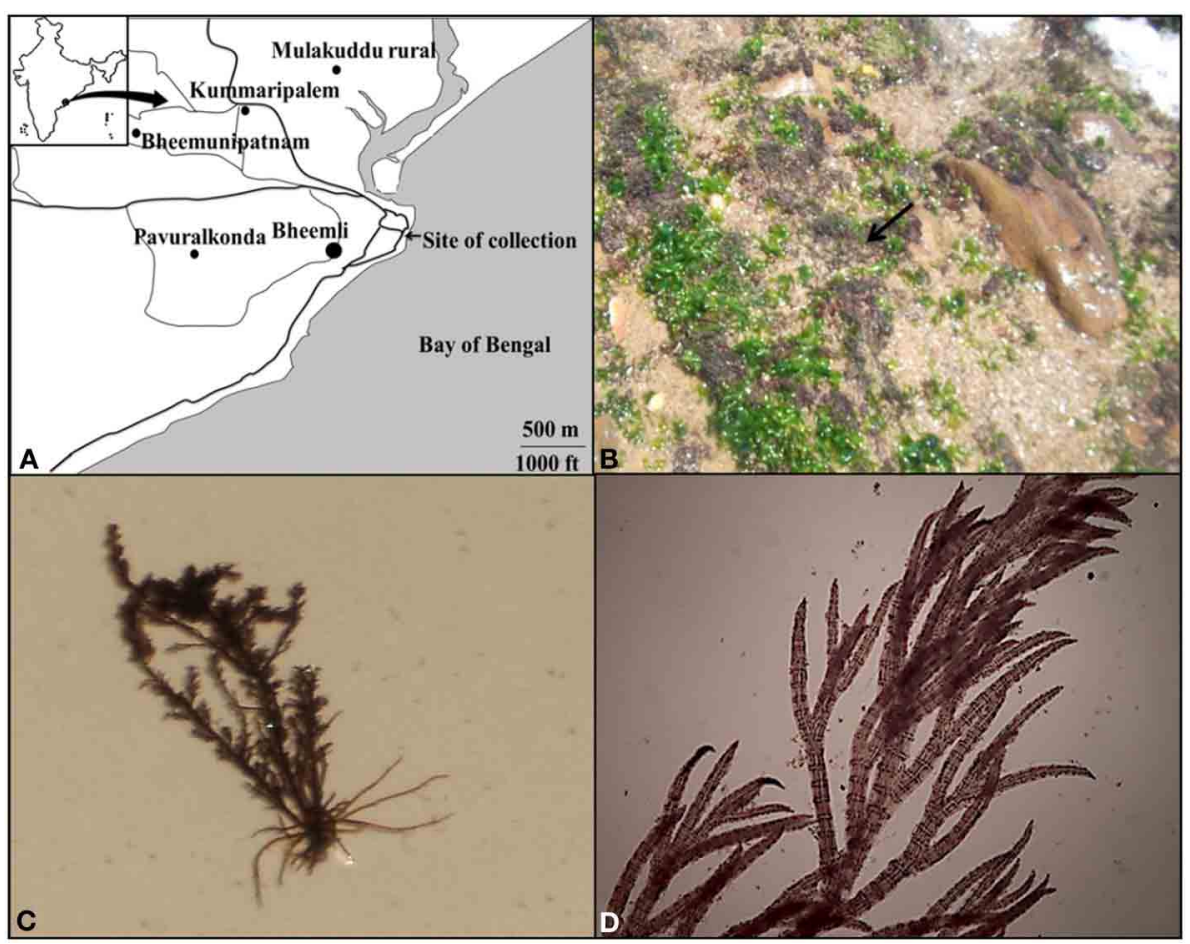

FIGURE 1 | Map of sampling area (Bheemli beach, Vishakhapatnam, Andhra Pradesh, India) (A), Aerial view of red brown algal mat of Bryocladia sp. on rock surface (arrow) (B), Morphology (C), and microscopic view of the collected alga (D). 


\section{HIGH PERFORMANCE LIQUID CHROMATOGRAPHY AND QUANTIFICATION OF MAAs}

MAAs were analyzed with HPLC (Water 2998 with PDA detector, 515 PUMP, auto injector 717 plus, Milford, USA) equipped with Empower-2 software. The system has an ODS-2 (RP18) column (Water, Spherisorb analytical column, $5 \mu \mathrm{m}, 4.6 \times 250 \mathrm{~mm}$ diameter, Ireland) along with guard $(4.6 \times 10 \mathrm{~mm})$. A $50 \mu \mathrm{l} \mathrm{sam}-$ ple volume was used for injection and $0.2 \%$ acetic acid was used as mobile phase. The wavelength of detection was $330 \mathrm{~nm}$ with a flow rate of $1 \mathrm{ml} \mathrm{min}^{-1}$. The compounds showing variable peaks were eluted and lyophilized. The quantification of MAAs was carried out by using molar extinction coefficient of standard MAAs (P-334).

\section{ABSORPTION SPECTROSCOPY}

The spectroscopic analysis of the water soluble aliquots was performed by using a UV-Vis double beam spectrophotometer (U-2910, 2J1-0012, Hitachi, Tokyo, Japan) in the range of 200-700 nm. The raw spectra were transferred to computer and peaks were analyzed by UV-solution software (Version-2.2, Hitachi, Tokyo, Japan).

\section{DETERMINATION OF PHOTOSYNTHETIC PIGMENTS}

Extraction of Chl $a$ from Bryocladia sp. was carried out by the method as described by Tripathi (1983). Samples were sonicated ( $130 \mathrm{~W}, 20 \mathrm{kHz}$; Sonic and Materials, USA) with sodium carbonate in $80 \%$ acetone and kept for $15 \mathrm{~min}$ at $80^{\circ} \mathrm{C}$ in a water bath. The supernatant obtained after centrifugation was stored and pellet was repeatedly washed with acetone till the pellet became colorless. The pool supernatants were mixed with equal volume of water and petroleum ether followed by centrifugation at $5000 \times \mathrm{g}$ for $15 \mathrm{~min}$. The green top layer of supernatant was collected and lyophilized to evaporate the petroleum ether. Dried pellet was further dissolved in $80 \%$ acetone $(3 \mathrm{ml})$ and spectra were taken in a UV-Vis spectrophotometer. Quantification of chlorophyll $a$ and carotenoids were carried out by the formula as described by Mackinney (1941) and Myers and Kratz (1955), respectively.

\section{CELLULAR PROTEIN CONTENTS}

Cellular protein was extracted by using the method of Wagner et al. (2002). Quantification of protein was done by measuring the absorbance of samples at both 280 and $260 \mathrm{~nm}$ and applying a correction formula of Warburg and Christian (1942).

\section{PEROXIDE STABILITY AND SCAVENGING POTENTIAL OF MAAs}

Peroxide stability and scavenging potential of MAAs was analyzed in the presence of hydrogen peroxide. For the analysis of stability of MAAs, $30 \% \mathrm{H}_{2} \mathrm{O}_{2}(0-10 \mathrm{mM})$ was mixed with $0.074 \mathrm{mmol}$. $\mathrm{g}$ dry wt ${ }^{-1}$ of different MAAs and absorbance was taken at 323, 328, 335 , and $340 \mathrm{~nm}$ by UV-Vis spectrophotometer after 5 and $30 \mathrm{~min}$ of incubation at $20 \pm 5^{\circ} \mathrm{C}$. The stability was analyzed by the percentage inhibition. The quantification of scavenging potential of MAAs against peroxide was determined by the relationship between absorbance of different MAAs and $\mathrm{H}_{2} \mathrm{O}_{2}(240 \mathrm{~nm})$. The molar extinction coefficient of $\mathrm{H}_{2} \mathrm{O}_{2}\left(43.6 \mathrm{M}^{-1} \mathrm{~cm}^{-1}\right)$ was used for the calculation of relative inhibition.

\section{STATISTICAL ANALYSIS}

All the experiments were conducted in triplicate. Results were expressed as mean $\pm \mathrm{SD}(n=3)$. A One Way ANOVA was applied for the statistical $(P \leq 0.05)$ analysis. Sigma plot 11 and SPSS-16 software were used for the purpose of statistical analyses.

\section{RESULTS}

HIGH-PERFORMANCE LIQUID CHROMATOGRAPHY ANALYSIS OF MAAs

Mycosporine-like amino acids were extracted in Mili Q water and purified by high performance liquid chromatography (HPLC). Four peaks at retention times $2.65,2.94,3.23$, and $3.56 \mathrm{~min}$ (Figure 2A) having absorption maxima at 340, 328, 323, and

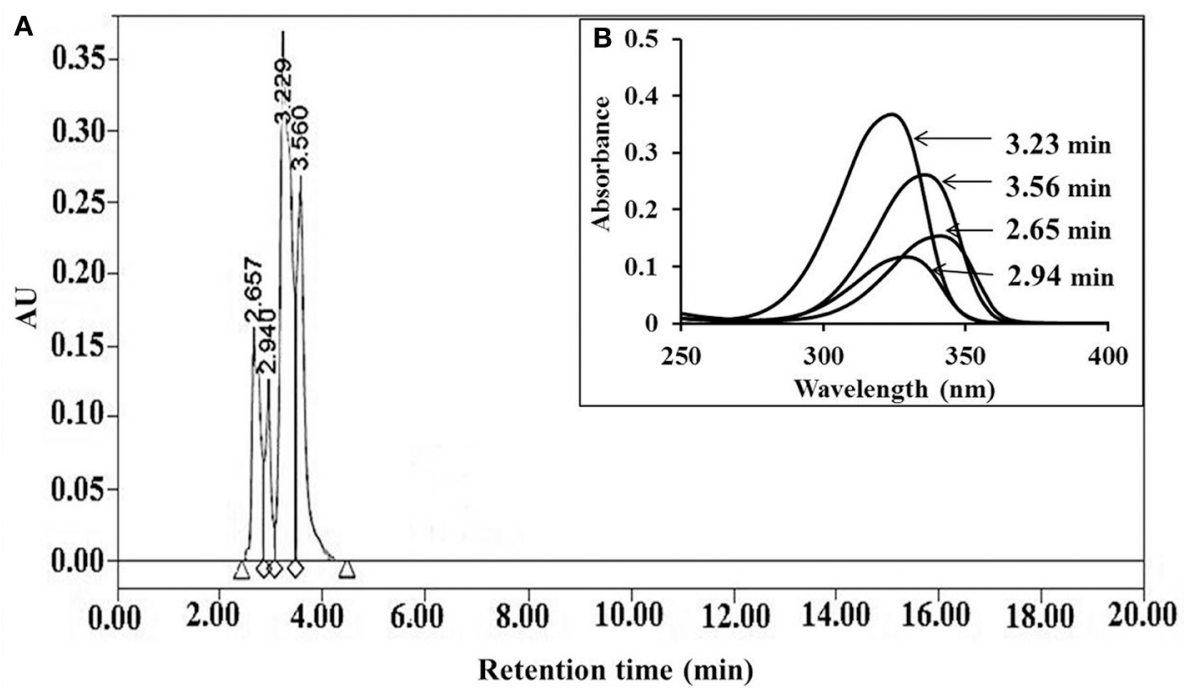

FIGURE 2 | HPLC chromatogram of MAAs extracted from Bryocladia sp., showing retention times 2.65, 2.94, 3.56, and 3.23 min (A) with corresponding absorption maxima $340,328,335$, and $323 \mathrm{~nm}$, respectively (B). 
$335 \mathrm{~nm}$, respectively, were eluted (Figure 2B). Eluted MAAs were collected and lyophilized for oxidative analyses.

\section{INDUCTION OF MAAs}

MAAs were induced by UV-B irradiation $\left(\sim 1 \mathrm{Wm}^{-2}\right)$ (Figure 3A). Absorption spectrum obtained from HPLC showed significant induction of MAAs at wavelength $323 \mathrm{~nm}$ (RT $3.23 \mathrm{~min}$ ) after $24 \mathrm{~h}$ of exposure in comparison to control. However, MAAs at 328 (RT $2.94 \mathrm{~min}$ ), 335 (RT $3.56 \mathrm{~min}$ ), and $340 \mathrm{~nm}$ (RT $2.65 \mathrm{~min}$ ) were significantly induced up to $12 \mathrm{~h}$ of irradiation (Figure 3B). There was 22\% induction in MAAs concentration as compared to control at $3.23 \mathrm{~min}$ with significant $p$-value $(<0.05)$ after $24 \mathrm{~h}$ of exposure, whereas MAAs at $2.65(5.3 \%), 2.94(3.7 \%)$, and $3.56(11.6 \%)$ min retention

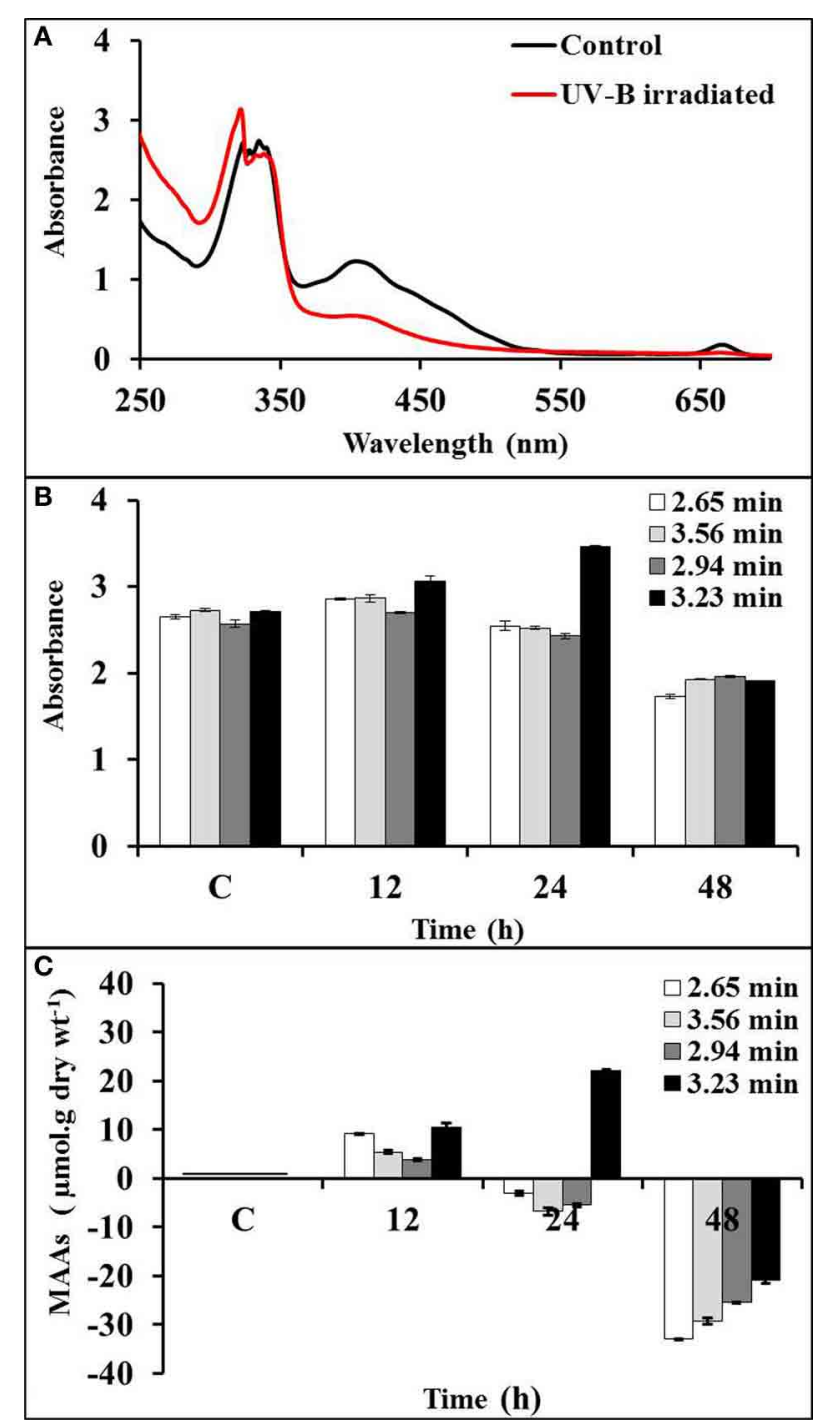

FIGURE 3 | Absorption spectra of control and UV-B irradiated Bryocladia sp. extracts (A) and showing relative induction of MAAs at retention times $2.65\left(\lambda_{\max } 340 \mathrm{~nm}\right), 2.94\left(\lambda_{\max } 328 \mathrm{~nm}\right), 3.56\left(\lambda_{\max }\right.$ $335 \mathrm{~nm}$ ), and $3.23 \mathrm{~min}\left(\lambda_{\max } 323 \mathrm{~nm}\right)$ after 12, 24, and $48 \mathrm{~h}$ of UV-B irradiation (B). Actual percentage induction/reduction of MAAs (C). times were comparatively less induced after $12 \mathrm{~h}$ of exposure. Further exposure resulted in the decline of MAAs concentration (Figure 3C). There was $42 \%$ reduction in MAAs concentration at $3.23 \mathrm{~min}$ after $48 \mathrm{~h}$ of exposure. Similarly, peak maxima with retention time of $2.65,2.94$, and $3.56 \mathrm{~min}$ showed significant $(25-33 \%)$ decline $(p<0.05)$ after 48 h of exposure.

\section{IMPACT OF UV-B ON PIGMENTS AND CELLULAR PROTEINS}

The amount of chlorophyll ( $\operatorname{chl} a$ ) had declined up to 34,66 , and $98 \%$ after 12,24 , and $48 \mathrm{~h}$ of UV-B radiation, respectively (Figure 4A). However, the concentration of carotenoids was declined up to 33,50 , and $72 \%$ after 12,24 , and $48 \mathrm{~h}$ exposure of UV-B radiation, respectively (Figure 4B). The level of protein was significantly declined $23 \%$ after $12 \mathrm{~h}$ of exposure; however, it reached up to $40 \%$ after $48 \mathrm{~h}$ of UV-B irradiation (Figure 4C).

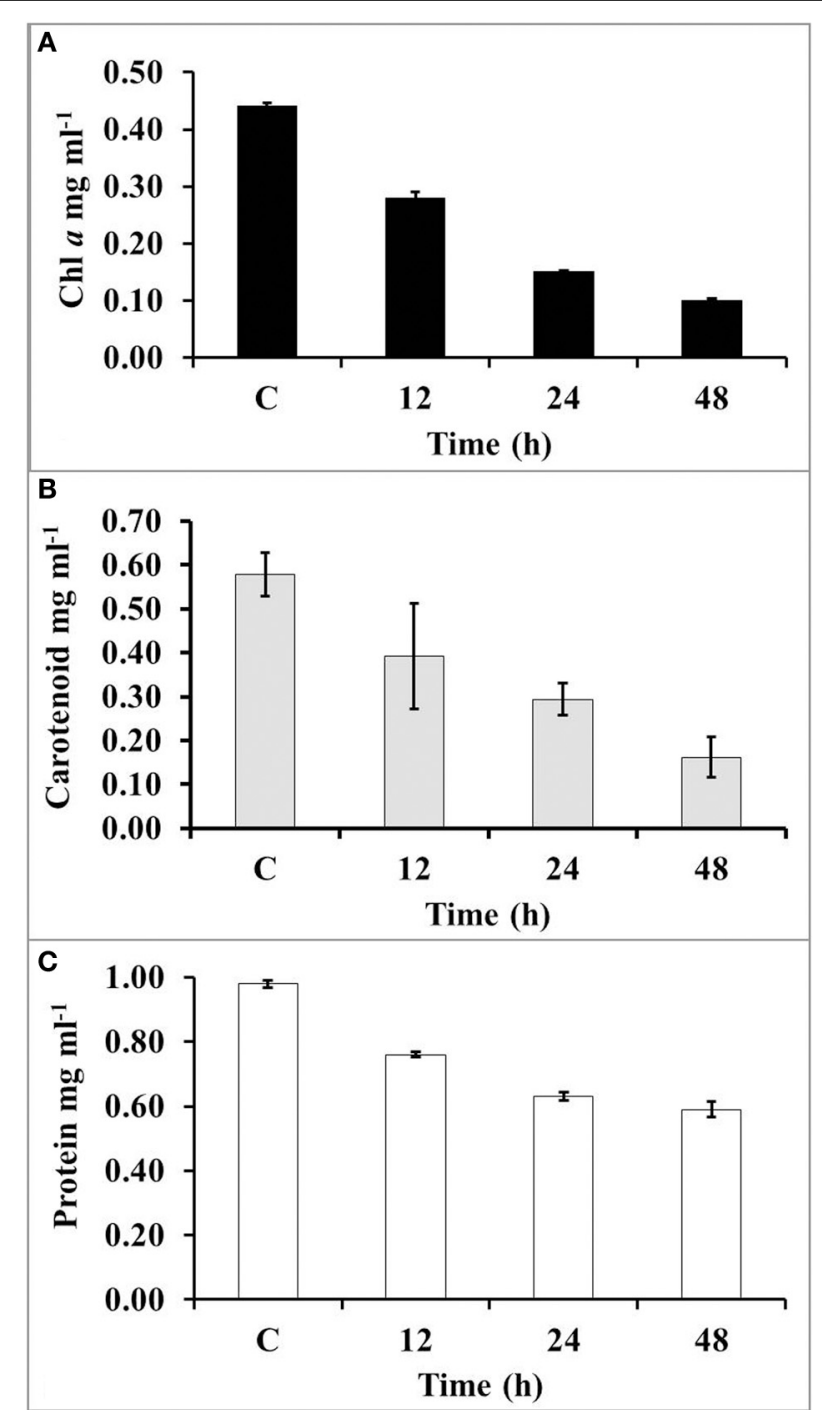

FIGURE 4 | The concentration of chl a (A), carotenoids (B), and total protein (C) after increasing time period of UV-B irradiation. 


\section{STABILITY AND SCAVENGING POTENTIAL OF MAAs}

The overall stability of MAAs and their antioxidative behavior were analyzed by the treatment with different concentration (0-10 mM) of $\mathrm{H}_{2} \mathrm{O}_{2}$ (Figure 5). MAAs were significantly stable at $2 \mathrm{mM}$ of $\mathrm{H}_{2} \mathrm{O}_{2}$ concentration. The increase $(4-10 \mathrm{mM})$ in the concentration of $\mathrm{H}_{2} \mathrm{O}_{2}$ resulted in continuous decline in the absorbance maxima with a slight peak shift toward the shorter wavelength indicating the decline in absorbance of MAAs along with increasing absorbance of $\mathrm{H}_{2} \mathrm{O}_{2}$ at $240 \mathrm{~nm}$.

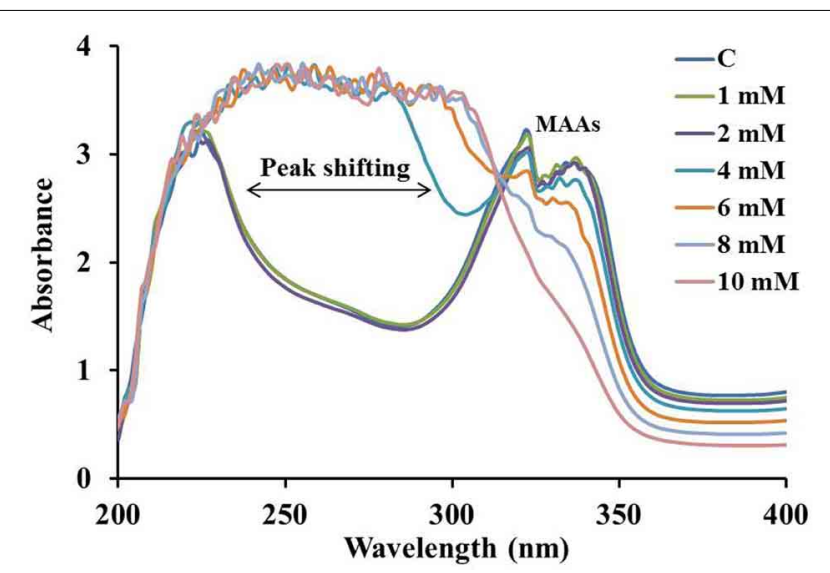

FIGURE 5 | Absorption spectrum of MAAs $\left(0.075 \mathrm{mmol}^{\mathrm{g}} \mathrm{dry}_{\mathbf{w t}} \mathrm{wt}^{-1}\right)$ in 0-10 $\mathrm{mM}$ of $\mathrm{H}_{2} \mathrm{O}_{2}(30 \%)$ showing peak shifting toward shorter wavelengths with increasing peroxide concentration.

\section{STABILITY OF MAAs IN PEROXIDE TOXICITY}

The stability of MAAs was analyzed in the presence of $0-10 \mathrm{mM}$ $\mathrm{H}_{2} \mathrm{O}_{2}$ concentration with an incubation period of 5 and $30 \mathrm{~min}$. Spectrophotometric analysis showed that MAAs were stable (>95\%) up to $2 \mathrm{mM}$ concentration of $\mathrm{H}_{2} \mathrm{O}_{2}$. Thereafter, there was a gradual decline in the MAAs concentration with increasing $(4-10 \mathrm{mM})$ concentration of $\mathrm{H}_{2} \mathrm{O}_{2}$. Figure 6A indicates only 4 and $5 \%$ decline in MAAs concentration $(323 \mathrm{~nm}$ ) with $2 \mathrm{mM}$ $\mathrm{H}_{2} \mathrm{O}_{2}$ after 5 and $30 \mathrm{~min}$ of incubation, respectively. However, further increase in $\mathrm{H}_{2} \mathrm{O}_{2}$ concentration $(10 \mathrm{mM})$ had resulted 45 and $50 \%$ decline in MAAs concentration after 5 and 30 min of incubation, respectively. Similarily, the concentration of MAAs at wavelengths of 328 and $335 \mathrm{~nm}$ had declined up to $35-44 \%$ and $49-58 \%$ after 5 and $30 \mathrm{~min}$, respectively, after incubation at $10 \mathrm{mM} \mathrm{H}_{2} \mathrm{O}_{2}$ concentration (Figures 6B,C). Interestingly, MAAs at $340 \mathrm{~nm}$ had invariably reduced (48-68\%) after 5 and $30 \mathrm{~min}$ of incubation at $10 \mathrm{mM} \mathrm{H}_{2} \mathrm{O}_{2}$, suggesting that this MAA was less stable after 30 min of incubation in $\mathrm{H}_{2} \mathrm{O}_{2}$ (Figure 6D).

\section{PEROXIDE SCAVENGING POTENTIAL OF MAAs}

All the purified MAAs effectively scavenges $\mathrm{H}_{2} \mathrm{O}_{2}$ upto a concentration of $\leq 2 \mathrm{mM}$. There was negligible decline in MAAs (323 and $328 \mathrm{~nm}$ ) concentration as compared to control ( $0.075 \mathrm{mmol} . \mathrm{g}$ dry $\mathrm{wt}^{-1}$ ) up to $2 \mathrm{mM} \mathrm{H}_{2} \mathrm{O}_{2}$ (Figures 7A,B). However, other MAAs (335 and $340 \mathrm{~nm}$ ) were declined up to 0.008 and $0.012 \mathrm{mmol} . \mathrm{g}$ dry $\mathrm{wt}^{-1}$ after $2 \mathrm{mM} \mathrm{H}_{2} \mathrm{O}_{2}$ treatment (Figures 7C,D). Further increase in $\mathrm{H}_{2} \mathrm{O}_{2}$ concentration $(10 \mathrm{mM})$, the MAAs at wavelengths $323,328,335$, and $340 \mathrm{~nm}$ had declined up to $0.026,0.036$, 0.029 , and $0.021 \mathrm{mmol} . \mathrm{g}$ dry $\mathrm{wt}^{-1}$, respectively.

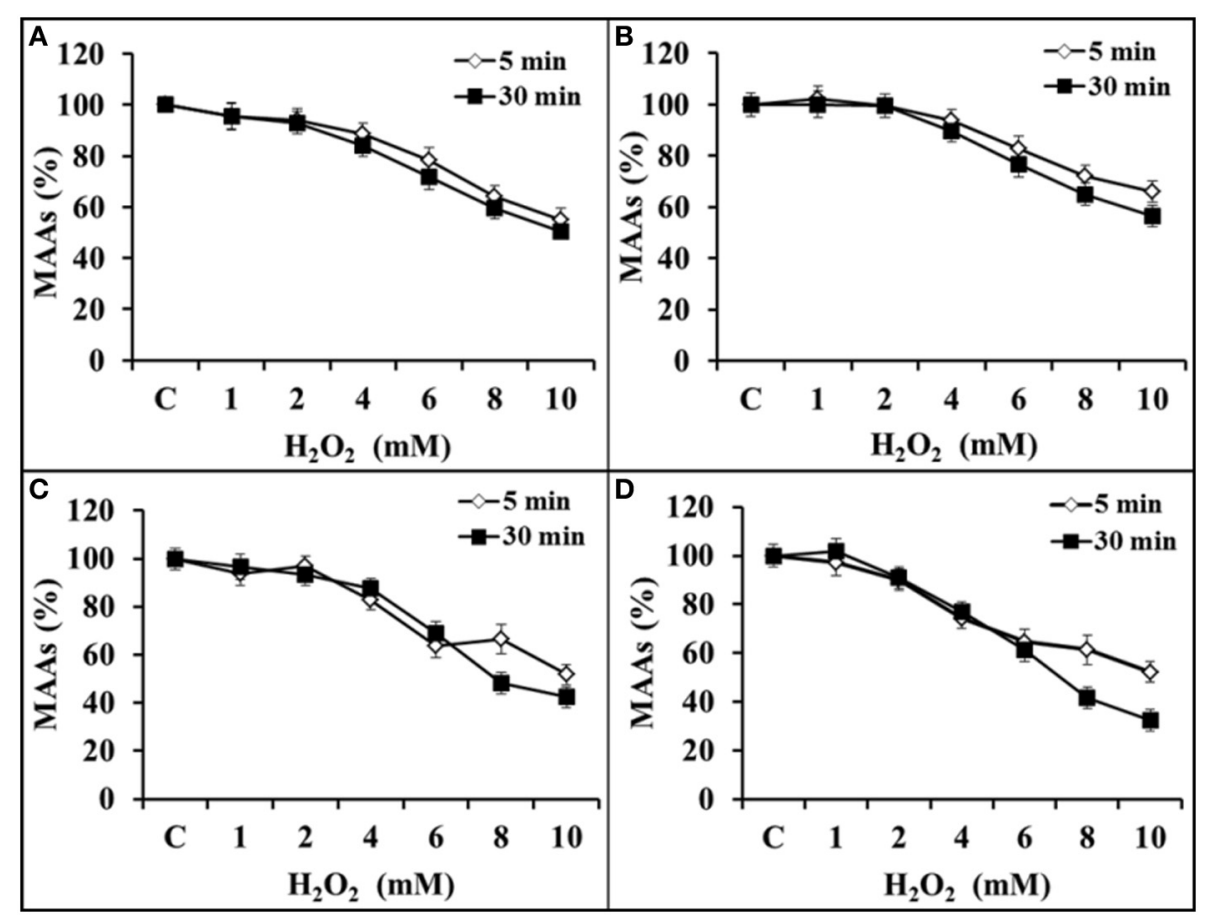

FIGURE 6 | Percentage inhibition of MAAs $\left(0.075 \mathrm{mmol}\right.$.g dry wt $\left.{ }^{-1}\right)$ against $\mathrm{H}_{2} \mathrm{O}_{2}(0-10 \mathrm{mM})$ at $323 \mathrm{~nm}(A), 328 \mathrm{~nm}$ (B), $335 \mathrm{~nm}$ (C), and $340 \mathrm{~nm}$ (D) after 5 and 30 min of incubation in $\mathrm{H}_{2} \mathrm{O}_{2}$. 


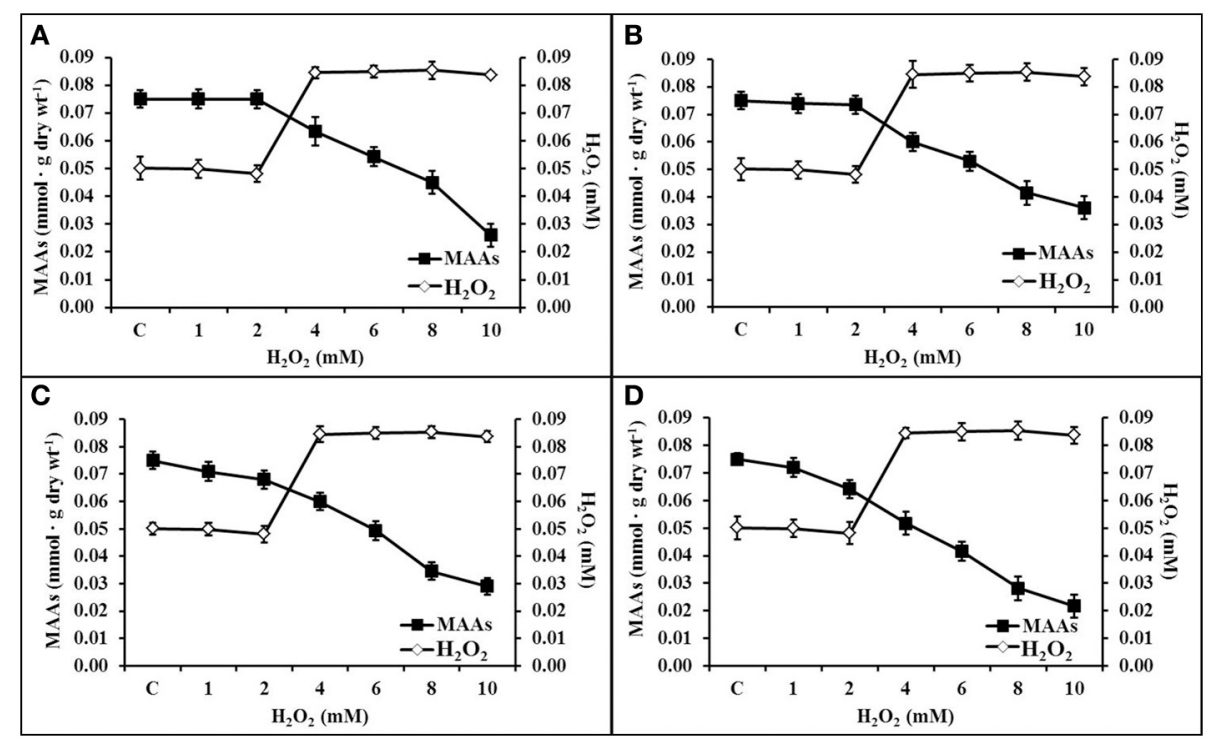

FIGURE 7 | Diagonal relationship of scavenging potential of MAAs in different concentrations of $\mathbf{H}_{\mathbf{2}} \mathrm{O}_{\mathbf{2}}(\mathbf{0}-\mathbf{1 0} \mathbf{m M})$. Inactivation of $\mathrm{H}_{2} \mathrm{O}_{2}$ by $M A A s$ at $323 \mathrm{~nm}$ (A), $328 \mathrm{~nm}$ (B), $335 \mathrm{~nm}$ (C), and $340 \mathrm{~nm}$ (D).

\section{DISCUSSION}

It is well established that highly energetic UV-B radiation is deleterious to all living organisms on the Earth's surface (Sinha et al., 2000). It has been reported that UV-B radiation promotes oxidative damage due to the overproduction of ROS inside the cells of several algae, cyanobacteria and plants (Rijstenbil, 2002; Shiu and Lee, 2005). $\mathrm{H}_{2} \mathrm{O}_{2}$ is the principle component of ROS that is initiated by UV-B irradiation in red algae (Lee and Shiu, 2009).

To cope up with such harsh oxidative conditions organisms have developed stress inhibition compounds that minimize the deterioration of biosynthetic, metabolic and native protein components with stable amino acids orientation. The database of one such UV-absorbing compounds MAAs has been reported in fungi, cyanobacteria, macroalgae, phytoplankton and animals (Sinha et al., 2007). MAAs are protective agent in living organisms that prevent 3 out of 10 photons of UV-B radiation thereby providing protection from irradiation to cyanobacteria (GarciaPichel et al., 1993). The algae of median tidal area are more efficient in producing UV-B screening compounds to cope up with its deleterious effect (van de Poll et al., 2003). Our results indicate that MAAs are inducible with UV-B radiation and can maintain good stability in peroxide stress conditions. Induction of MAA having RT $3.23 \mathrm{~min}(323 \mathrm{~nm})$ after UV-B irradiation is unique in red algae because this MAA is more static in the range of 330-340 nm. Rastogi and Incharoensakdi (2013) have recently reported the presence of MAAs at 322 and $324 \mathrm{~nm}$ wavelengths in fresh water alga Tetraspora sp. CU2551 species that have potent photoprotective and antioxidative properties.

After UV-B irradiation, the chl $a$ and carotenoids have been reported to be bleached due to the photooxidation of endogenous chromophores (Marwood and Greenberg, 1996; Sinha et al., 2000). Sinha et al. (2000) reported similar result of continuous decline in absorption peak at 665 and $475 \mathrm{~nm}$ in the red alga
Gracilaria cornea after UV-B radiation. The stability of growth and photosynthetic pigments in algae depends on the adaptation of species in harsh environmental conditions (Karsten et al., 2007). Production of antioxidative enzymes and induction of MAAs may help the organisms to reduce the impact of UV-B irradiation (Sinha et al., 2000; Rastogi et al., 2011). As stated earlier, UV-B irradiation induces the production of more ROS including peroxide and to cope up with this harsh condition of oxidative damage organisms have developed the ability to synthesize photoprotective MAAs. An oxo-carbonyl derivative linked MAAs have oxidative inhibition properties while imino-MAAs (P-334 and shinorine) present in red alga Gracilaria cornea are oxidatively inert (Sinha et al., 2000). We have first analyzed the in vitro effects of hydrogen peroxide on algal MAAs with a view to illustrate their level of stability and scavenging properties against ROS. It has been reported that mycosporine-glycine have oxidative quenching ability to protect the biological system against light oriented damage (Suh et al., 2003).

\section{ACKNOWLEDGMENTS}

Vinod K. Kannaujiya is thankful to the Council of Scientific and Industrial Research (CSIR), New Delhi for financial assistance in the form of senior research fellowship. The work was also partially supported by the Department of Science and Technology sponsored project (No. SR/WOS-A/LS-140/2011) sanctioned to Ms. Richa.

\section{REFERENCES}

Ballaré, C. L., Caldwell, M. M., Flint, S. D., Robinson, S. A., and Bornman, J. F. (2011). Effects of solar ultraviolet radiation on terrestrial ecosystems. Patterns, mechanisms, and interactions with climate change. Photochem. Photobiol. Sci. 10, 226-241. doi: 10.1039/c0pp90035d

Conde, F. R., Churio, M. S., and Previtali, C. M. (2000). The photoprotector mechanism of mycosporine-like amino acids. Excited-state 
properties and photostability of porphyra-334 in aqueous solution. J. Photochem. Photobiol. B Biol. 56, 139-144. doi: 10.1016/S1011-1344(00) 00066-X

Crutzen, P. J. (1992). Ultraviolet on the increase. Nature 356, 104-105. doi: $10.1038 / 356104 \mathrm{a} 0$

Dunlap, W. C., and Shick, J. M. (1998). Ultraviolet radiation-absorbing mycosporine-like amino acids in coral reef organism: a biochemical and environmental perspective. J. Phycol. 34, 418-430. doi: 10.1046/j.15298817.1998.340418.x

Foyer, C. H., Lelandais, M., and Kunert, K. J. (1994). Photooxidative stress in plants. Physiol. Plant 92, 696-717. doi: 10.1111/j.1399-3054.1994.tb03042.x

Garcia-Pichel, F., Wingard, C. E., and Castenholz, R. W. (1993). Evidence regarding the UV sunscreen role of a mycosporine-like compound in the cyanobacterium Gloeocapsa sp. Appl. Environ. Microbiol. 59, 170-176.

Häder, D.-P. (1993). Risk for enhanced solar ultraviolet radiation for aquatic ecosystems. Prog. Phycol. Res. 9, 1-45.

Häder, D.-P., Helbling, E. W., Williamson, C. E., and Worrest, R. C. (2011). Effects of UV radiation on aquatic ecosystems and interactions with climate change. Photochem. Photobiol. Sci. 10, 242-260. doi: 10.1039/c0pp $90036 \mathrm{~b}$

He, Y. Y., and Häder, D.-P. (2002). Reactive oxygen species and UV-B: effect on cyanobacteria. Photochem. Photobiol. Sci. 1, 729-736. doi: 10.1039/b11 $0365 \mathrm{~m}$

Hoffman, D. J., and Deshler, T. (1991). Evidence from balloon measurements for chemical depletion of stratospheric ozone in the Arctic winter of 1989-90. Nature 349, 300-305. doi: 10.1038/349300a0

Janknegt, P. J., van de Poll, W. H., Visser, R. J. W., Rijstenbil, J. W., and Boma, A. G. J. (2008). Oxidative stress responses in the marine Antarctic diatom Chaetocerosbrevis (Bacillariophyceae) during photoacclimation. J. Phycol. 44, 957-966. doi: 10.1111/j.1529-8817.2008.00553.x

Karsten, U., Lembcke, S., and Schumann, R. (2007). The effects of ultraviolet radiation on photosynthetic performance, growth and sunscreen compounds in aero terrestrial biofilm algae isolated from building facades. Planta 225, 991-1000. doi: 10.1007/s00425-006-0406-x

Karyotou, K., and Donaldson, R. P. (2005). Ascorbate peroxidase, a scavenger of hydrogen peroxide in glyoxysomal membranes. Arch. Biochem. Biophys. 434, 248-257. doi: 10.1016/j.abb.2004.11.003

Langebartels, C., Schraudner, M., Heller, W., Ernst, D., and Sandermann, H. (2000). "Oxidative stress and defense reactions in plants exposed to air pollutants and UV-B radiation," in: Oxidative Stress in Plants, eds D. Inze and M. Van Montagu (Amsterdam: Harwood Academic Publishers), 105-135.

Lee, T.-M., and Shiu, C.-T. (2009). Implications of mycosporine-like amino acid and antioxidant defenses in UV-B radiation tolerance for the algae species Ptercladiella capillacea and Gelidium amansii. Mar. Environ. Res. 67, 8-16. doi: 10.1016/j.marenvres.2008.09.006

Mackinney, G. (1941). Absorption of light by chloroplast solution. J. Biol. Chem. 140, 315-322.

Madronich, S., McKenzie, R., Bjorn, R., and Caldwell, M. (1998). Changes in biologically active ultraviolet radiation reaching the Earth's surface. J. Photochem. Photobiol. B Biol. 46, 5-19. doi: 10.1016/S1011-1344(98)00182-1

Marwood, C. A., and Greenberg, B. M. (1996). Effect of supplementary UV-B radiation on chlorophyll synthesis and accumulation of photosystems during chloroplast development in Spirodela oligorrhiza. Photochem. Photobiol. 64, 664-670. doi: 10.1111/j.1751-1097.1996.tb03121.x

Myers, J., and Kratz, W. A. (1955). Relationship between pigment content and photosynthetic characteristics in blue-green algae. J. Gen. Physiol. 39, 11-21. doi: 10.1085/jgp.39.1.11

Nakamura, H., Kobayashi, J., and Hirata, Y. (1982). Separation of mycosporinelike amino acids in marine organisms using reverse-phase high performance liquid chromatography. J. Chromatogr. A 250, 113-118. doi: 10.1016/S00219673(00)95219-1

Pessoa, M. F. (2012). Harmful effects of UV radiation in algae and aquatic macrophytes -a review. Emir. J. Food Agric. 24, 510-526. doi: 10.9755/ejfa.v24i6. 510526

Rastogi, R. P., and Incharoensakdi, A. (2013). UV radiation-induced accumulation of photoprotective compounds in the green alga Tetraspora sp. CU2551. Plant Physiol. Biochem. 70, 7-13. doi: 10.1016/j.plaphy.2013. 04.021
Rastogi, R. P., Singh, S. P., Häder, D.-P., and Sinha, R. P. (2011). UltravioletB-induced DNA damage and photorepair in the cyanobacterium Anabaena variabilis PCC 7937. Environ. Exp. Bot. 74, 280-288. doi: 10.1016/j.envexpbot.2011.06.010

Ravishankara, A. R., Danie, J. S., and Portmann, R. W. (2009). Nitrous oxide ( $\left.\mathrm{N}_{2} \mathrm{O}\right)$ : the dominant ozone-depleting substance emitted in the 21 st century. Science 326, 123-125. doi: 10.1126/science.1176985

Richa., Kumari, S., Kannaujiya, V. K., Mishra, S., and Sinha, R. P. (2013). Response of a Hot-spring Cyanobacterium Scytonema sp. strain HKAR-3 to ultraviolet-B radiation. Int. J. Curr. Biotechnol. 10, 32-36.

Riegger, L., and Robinson, D. (1997). Photoinduction of UV-absorbing compounds in Antarctic diatoms and Phaeocystis antarctica. Mar. Ecol. Prog. Ser. 160, 13-25. doi: 10.3354/meps 160013

Rijstenbil, J. W. (2002). Assessment of oxidative stress in the planktonic diatom Thalassiosira pseudonana in response to UVA and UVB radiation. J. Plankton Res. 24, 1277-1288. doi: 10.1093/plankt/24.12.1277

Russell, J. M., Luo, M. Z., Cicerone, R. J., and Deaver, L. E. (1996). Satellite confirmation of the dominance of chloroflurocarbons in the global stratospheric chlorine budget. Nature 379, 526-529. doi: 10.1038/379526a0

Sahoo, A., Sarkar, S., Singh, R. P., Kafatos, M., and Summers, M. E. (2005). Declining trend of total ozone column over the northern parts of India. Int. J. Remote Sens. 26, 33-40. doi: 10.1080/01431160500076467

Sahoo, D., Nivedita., and Debasish. (2001). Seaweeds of Indian Coast. New Delhi: A.P.H. Publishing.

Shick, J. M., and Dunlap, W. C. (2002). Mycosporine-like amino acids and related gadusols: biosynthesis, accumulation and UV-protective functions in aquatic organisms. Annu. Rev. Physiol. 64, 223-262. doi: 10.1146/annurev.physiol.64.081501.155802

Shimizu, T., Kanamori, Y., Furuki, T., Kikawada, H., Okuda, T., Takahashi, T., et al. (2010). Desiccation-induced structuralization and glass formation of group 3 late embryogenesis abundant protein model peptides. Biochemistry 49, 1092-1104. doi: 10.1021/bi901745f

Shiu, C.-T., and Lee, T.-M. (2005). Ultraviolet-B-induced oxidative stress and responses of the ascorbate-glutathione cycle in a marine macroalga Ulva fasciata. J. Exp. Bot. 56, 2851-2865. doi: 10.1093/jxb/eri277

Sinha, R. P., Klisch, M., Gröniger, A., and Häder, D.-P. (2000). Mycosporine-like amino acids in the marine red alga Gracilaria cornea - effects of UV and heat. Environ. Exp. Bot. 43, 33-43. doi: 10.1016/S0098-8472(99)00043-X

Sinha, R. P., Klisch, M., and Häder, D.-P. (1999). Induction of a mycosporinelike amino acid (MAA) in the rice-field cyanobacterium Anabaena sp. by UV irradiation. J. Photochem. Photobiol. B Biol. 52, 59-64. doi: 10.1016/S10111344(99)00103-7

Sinha, R. P., Singh, S. P., and Häder, D.-P. (2007). Database on mycosporines and mycosporine-like amino acids (MAAs) in fungi, cyanobacteria, macroalgae, phytoplankton and animals. J. Photochem. Photobiol. B Biol. 89, 29-35. doi: 10.1016/j.jphotobiol.2007.07.006

Smith, R. C., Prezelin, B. B., and Baker, K. S. (1992). Ozone depletion: ultraviolet radiation and phytoplankton biology in Antarctic waters. Science 255, 952-959. doi: $10.1126 /$ science. 1546292

Suh, H.-J., Lee, H.-W., and Jung, J. (2003). Mycosporine glycine protects biological systems against photodynamic damage by quenching single oxygen with a high efficiency. Photochem. Photobiol. 78, 109-113. doi: 10.1562/00318655(2003)078<0109:MGPBSA > 2.0.CO;2

Tripathi, S. N. (1983). Effect of temperature on chlorophyll stability of some subaerial blue-green algae. Z. Allge. Mikrobiol. 23, 443-446. doi: 10.1002/jobm.3630230711

van de Poll, W. H., Bischof, K., and Buma, A. G. J. (2003). Habitat related variation in UV tolerance of tropical marine red macrophytes is not temperature dependent. Physiol. Plantar. 118, 74-83. doi: 10.1034/j.1399-3054.2003.00090.x

Wada, N., Sakamoto, T., and Matsugo, S. (2013). Multiple roles of photosynthetic and sunscreen pigments in cyanobacteria focusing on the oxidative stress. Metabolites 3, 463-483. doi: 10.3390/metabo3020463

Wagner, M. A., Eschenbrenner, M., Horn, T. A., Kraycer, J. A., Mujer, C. V., Hagius, S., et al. (2002). Global analysis of the Brucella melitensis proteome: identification of proteins expressed in laboratory grown culture. Proteomics 2, 1047-1060. doi: 10.1002/1615-9861(200208)2:8<1047::AID-PROT1047>3.0.CO;2-8

Warburg, O., and Christian, W. (1942). Isolation and crystallization of enolase. Biochem. Z. 310, 384-421. 
Conflict of Interest Statement: The authors declare that the research was conducted in the absence of any commercial or financial relationships that could be construed as a potential conflict of interest.

Received: 09 April 2014; accepted: 10 June 2014; published online: 25 June 2014. Citation: Kannaujiya VK, Richa and Sinha RP (2014) Peroxide scavenging potential of ultraviolet-B-absorbing mycosporine-like amino acids isolated from a marine red alga Bryocladia sp. Front. Environ. Sci. 2:26. doi: 10.3389/fenvs.2014.00026
This article was submitted to Environmental Toxicology, a section of the journal Frontiers in Environmental Science.

Copyright (C) 2014 Kannaujiya, Richa and Sinha. This is an open-access article distributed under the terms of the Creative Commons Attribution License (CC BY). The use, distribution or reproduction in other forums is permitted, provided the original author(s) or licensor are credited and that the original publication in this journal is cited, in accordance with accepted academic practice. No use, distribution or reproduction is permitted which does not comply with these terms. 